\title{
$\operatorname{CONF} \cdot 850506-8$
}

\section{CALCULATIONS OF PHYSICAL AND CHEMICAL REACTIONS PRODUCED IN IRRADIATED WATER CONTAINING DNA ${ }^{1}$}

\author{
H. A. Wright*, J. L. Mageef, R. N. Hamm*, A. Chatterjeet, \\ J. E. Turner*, and C. E. Klots* \\ "Health and Safety Research Division, Oak Ridge National Laboratory, \\ Oak Ridge, Tennessee 37831 USA

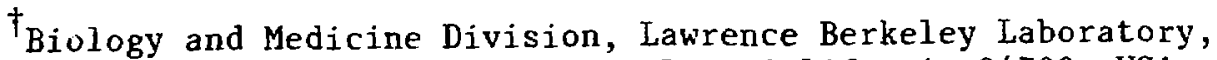 \\ University of California, Berkeley, California 94720 USA
}

Running Title: Reactions in Irradiated Water Containing DNA

\section{DISCLAIMER}

This report was prepared as an account of work sponsored by an agency of the United States Government. Neither the United States Government nor any agency thereof, nor any of their employees, makes any warranty, express or implied, or assumes any legal liability or responsibility for the accuracy, completeness, or usefulness of any information, apparatus, product, or process disclosed, or represents that its use would not infringe privately owned rights. Reference herein to any specific commercial product, process, or service by trade name, trademark, manufacturer, or otherwise does not necessarily constitute or imply its endorsement, recommendation, or favoring by the United States Government or any agency thereof. The views and opinions of authors expressed herein do not necessarily state or reflect those of the United States Goverament or any agency thereof.

\footnotetext{
By acceptance of this article, the publisher or recipient ecknowledges the U.S. Government's ripht to retein a nonexclusive, rovalty-tree license in and to any copyright covering the article.
}

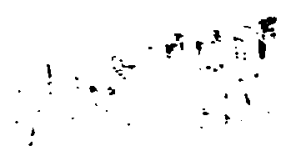

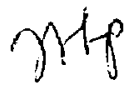




\section{Footnote}

${ }^{1}$ Research sponsored jointly by the Office of Health and Environmental Research, U.S. Department of Energy, under contract DE-AC05-840R21400 with Martin Marietta Energy Systems, Inc., and contract W-7405-48 with the Deputy for Electronic Technology, Air Force Systems Command, under Interagency Agreement DOE No. 40-226-70. 


\title{
CALCULATIONS OF PHYSICAL AND CHEMICAL REACTIONS PRODUCED
}

IN IRRADIATED WATER CONTAINING DNA

H. A. Wright, J. L. Magee, R. N. Hamm, A. Chatterjee, J. E. Turner, and C. E. Klots

\begin{abstract}
We present initial results obtained with a Monte Carlo computer program designed to link initial physical events in irradiated liquid water with subsequent chemical and biological events.
\end{abstract}




\section{Introduction}

A major problem in radiation chemistry and radiation biology is the determination of the relationship among initial physical interactions that occur folluwing the passage of a charged particle and are complete by $10^{-15} \mathrm{~s}$, later diffusion controlled chamical $r \in a c t i o n s$ which begin at approximately $10^{-11} \mathrm{~s}$ and are generally complete by $10^{-6} \mathrm{~s}$, and still later biological effects which may not become evident for years. In previous Microdosimetry Symposia in this series, we have described ${ }^{(1-4)}$ a Monte Carlo code to calculate the details of the initial physical interactions that charged particles undergo in liquid water. The code then calculates the position and identity of each reactant chemical species that is present at $10^{-11} \mathrm{~s}$ and follows each reactant through the diffusion and chemical reaction stage of charged-particle track development.

In this present paper we report initial results of an extension of our previous work to calculate reactions with biological molecules. For this study we have taken a simple model for a segment of a DNA molecule assumed to be in aqueous solution. We have performed calculations for protons and alpha particles that traverse the medium at various distances from the DNA molecule and have tabulated the number of direct physical and indirect chemical reations that occur with th. MA as a function of time after passage of the primary.

A description of our previous model to treat physical and chemical reactions has been published. ${ }^{(5)}$ We have re-examined the details of the pre-chemical and chemical reaction stages of our model, and we will briefly summarize here the significant improvements that have been made. A more comprehensive description of the present model will be published elsewhere. 


\section{Chemical Development of a Charged Particle Track}

The physical interactions, which are complete in a local region of the track by $10^{-15} \mathrm{~s}$, produce $\mathrm{H}_{2} \mathrm{O}^{+}, \mathrm{H}_{2} \mathrm{O}^{*}$ and subexcitation electrons, $e^{-}$. There is evidence ${ }^{(7-8)}$ that both the electron, $e^{-}$, anc the hole, $\mathrm{H}_{2} \mathrm{O}^{+}$, can migrate from the original reaction site before hydration occurs. For the present calculations we have assumed that when an $\mathrm{H}_{2} \mathrm{O}^{+}, e^{-}$pair is formed the electron moves a distance $d x, d y, d z$ where each is selected from a Gaussian distribution with $\mathrm{O}=3 \mathrm{~nm}$ and the $\mathrm{H}_{2} \mathrm{O}^{+}$moves in a similar manner with $\sigma=.75 \mathrm{~nm}$. These are the values that have been previously used for a single-pair spur.

\section{Treatment of Diffusion}

In the present calculations we have allowed reactants, starting at $10^{-11} \mathrm{~s}$, to undergo 30 elementary diffusive jumps, the jump time being taken as $3 \times 10^{-12} \mathrm{~s}$. After each jump those species that are close enough to each other react and are removed, and the remainder are jumped again. This procedure becomes inefficient after 30 jumps with very few reactions occurring after each jump. We have re-examined methods to simulate many jumps that can occur within a time $t$. We have found $(10)$ that good agreement can be obtained by assuming that the probability $P(t)$ that two species will have reacted by time $t$ is given by

$$
P(t)=\frac{a}{B} \operatorname{erfc} \frac{B-a}{(4 D+)^{\frac{1}{2}}}
$$

where $B$ is the initial separation, $D$ is the relative diffusion constant, erfc is the error function complement, and a is a "reduced" reaction radius given by

$$
a=R \frac{3 R P}{3 R P+2 \lambda}
$$

where $R$ is the reaction radius, $P$ the probability of reaction in a single encounter and $\lambda$ the jump distance. 
Table I gives the reactant species and diffusion constants that are used. Note that two additional reactant species, $\mathrm{OH}^{-}$and $\mathrm{H}_{2} \mathrm{O}_{2}$, have been added to the four that were used in our previous work, ${ }^{(5)}$ as well as two additional chemical reactions. Table II gives the chemical reactions, reaction radii, and reduced radii that are used. Fricke dosimeter chemical yields calculated by this program for electrons, protons, and alpha particles of several energies are in good agreement with experimental data. $(5,6)$ Model for DNA

In these initial calculations we have assumed a very crude model for a segment of double-stranded DNA. We assume the segment is a right circular cylinder of radius $I \mathrm{~nm}$ and that two types of reactive sites, designated as "base" and "sugar", alternate along two opposite helical strands on the surface of the cylinder. Each strand makes one turn in $3.4 \mathrm{~nm}$ and has 20 sites per turn which alternate between sugar and base. The reactions that are considered are shown in Table III. (For the initial charged particle transport, the DNA cylinder is treated as though it were water.)

\section{$\underline{\text { Results }}$}

For these calculations we have assumed the medium surrounding the DNA acts as a scavenger for the reactant species, and we have assumed the scavenge time to be $10^{-8} \mathrm{~s}$. Figure 1 shows the reactive sites on the DNA and the positions of reartant specier at $10^{-12} \mathrm{~s}$ from $60-\mathrm{nm}$ track segments of a 4-MeV alpha particle, a $1-\mathrm{MeV}$ proton, and a $10-\mathrm{MeV}$ proton. The figure gives one a feeling for the relative density of reactants with respect to the DNA.

Figure 2 shows an end view of the $4-\mathrm{MeV}$ alpha particle track segment from Figure 1 (at times of $10^{-12} \mathrm{~s}, 10^{-10} \mathrm{~s}$, and $10^{-8} \mathrm{~s}$ ) that passes the DNA at an impact parameter of $5 \mathrm{~nm}$. Here one can see the spreading of the reactants by diffusion and the reduction in number by reactions and scavenging. 
Since the scavenge time is taken to be $10^{-8} \mathrm{~s}$, the diffusion distance during this time is $\sim 20 \mathrm{~nm}$. We therefore consider a cylinder around the DNA of radius $20 \mathrm{~nm}$ and count the number of reactants that are in this cylinder due to the passage of the charged particle. This number will be, to first order, proportional to the dose in the cylinder, and thus we can compare results for different particles. In Figure 3 we show the number of reactions between two reactants and the number between one reactant and a site on the DNA normalized to the total number of reactants in the cylinder for $1-\mathrm{MeV}$ and $10-\mathrm{MeV}$ protons and for $4-\mathrm{MeV}$ alphas. The impact parameter is 0 (i.e., the particle passes through the center of the DNA). Since the alpha particle track is more dense there are a greater number of reactions between reactants leaving fewer reactants to react with DNA than for the proton tracks.

Figure 4 shows the total number of DNA interactions for protons and alpha particles as a function of energy. Since the stopping power is proportional to the square of the charge of the particle, one might expect the number of reactions from an alpha particle to be four times that for a proton. This is the approximate ratio at $10 \mathrm{MeV} / \mathrm{n}$ because the tracks are relatively tenuous. However, at $1 \mathrm{MeV} / \mathrm{n}$ the ratio is only about 2.5 reflecting the fact that there are more reactions between reactaints in the dense alpha track.

Concluding Remarks

These results have been obtained as part of a continuing program with the objectives of linking physical interactions with chemical and biological events and of identifying mechanisms that are important in producing biological effects. It is expectod that modifications and improvements will continue to be made, particularly in the model for DNA. In these calculations 
we have explored in a preliminary way the potential for this approach, and the results presented here are indicative of the type of information that can be obtained. 


\section{References}

1. Hamm, R. N., Wright, H. A., Ritchie, R. H., Turner, J. E., and Turner, T. P. Monte Carlo Calculation of Transport of Electrons through Liquid Water. Proceedings of the Fifth Symposium on Microdosimetry, Verbania, Italy, September 22-26, 1975, EUR 5452 d-e-f, pp. 1037-1053 (1976).

2. Ritchie, R. H., Hamm, R. N., Turner, J. E., and Wright, H. A. The Interaction of Swift Electrons with Liquid Water. Proceedings of the Sixth Symposium on Microdosimetry, Brussels, Belgium, May 22-26, 1978, EUR 6064 DE-EN-FR, pp. 345-354 (1978).

3. Turner, J. E., Magee, J. L., Hamm, R. N., Chatterjee, A., Wright, H. A., and Ritchie, R. H. Early Events in Irradiated Water. Proceedings of the Seventh Symposium on Microdosimetry, Oxford, England, September 8-12, 1980, EUR 7147 DE-EN-FR, Vol. I, pp. 507-517 (1981).

4. Wright, H. A., Magee, J. I., Turner, J. E., Chatterjee, A., Hamm, R. N., and Ritchie, R. H. Physical and Chemical Evolution of an Electron Track in Liquid Water. Proceedings of the Eighth Symposium on Microdosimetry, Jülich, West Germany, September 27-0ctober 1, 1982, EUR 8395 EN, pp. 101-109 (1983).

5. Turner, J. E., Magee, J. L., Wright, H. A., Chatterjee, A., Hamm, R. N., and Ritchie, R. H. Physical and Chemical Development of Electron Tracks in Liquid Water. Radiat. Res. 96, 437-449 (1983).

6. Wright, H. A., Magee, J. L., Hamm, R. N., Turner, J. E., and Chatterjee, A. Physical and Chemical Development of Proton and Alpha-Particle Tracks in Liquid Water (submitted).

7. Hamill, W. H. A Model for the Radiolysis of Water. J. Phys. Chem. 23 , 1341-1347 (1969).

8. Ogura, O. and Hamill, W. H. Positive Hole Migration in Pulse-Irradiated Water and Heavy Water. J. Phys. Chem. 77, 2952-2954 (1973).

9. Magee, J. L. and Chatterjee, A. A Spur Unfolding Mode: for the Radiolysis of Water. Radiat. Phys. Chem. 15, 125-132 (1980).

10. Klots, Cornelius E., Hamm, R. N., and Wright, H. A. On the Reaction of Isolated Pairs in Condensed Media. Journal of Chemical Physics (submitted). 


\section{Table Titles}

Table I. Reactant Species, Diffusion Constants, D, and Jump Distances, $\lambda$.

Table II. Chemical Reactions, Rate Constants, K, Reaction Radii, R, and Reduced Radii, a.

Table III. Reactions with DNA, Reaction Radii, R, and Reduced Radii, a. 


\begin{tabular}{lcc}
\hline Species & $\mathrm{D}\left(10^{-5} \mathrm{~cm}^{2} \mathrm{~s}^{-1}\right)$ & $\lambda(\mathrm{nm})$ \\
$\mathrm{OH}$ & 2.5 & .21 \\
$\mathrm{H}_{3} \mathrm{O}^{+}$ & 9.5 & .41 \\
$\mathrm{e}^{-}$ & 5.0 & .30 \\
$\mathrm{H}$ & 8.0 & .38 \\
$\mathrm{OH}^{-}$ & 5.3 & .31 \\
$\mathrm{H}_{2} \mathrm{O}_{2}$ & 1.4 & .16 \\
\hline
\end{tabular}

Table I 


\begin{tabular}{llcrr}
\hline Reaction & $\mathrm{K}\left(10^{10} \mathrm{dm}^{3} \mathrm{~mole}^{-1} \mathrm{~s}^{-1}\right)$ & $\mathrm{R}(\mathrm{nm})$ & $\mathrm{a}(\mathrm{nm})$ \\
$\mathrm{H}+\mathrm{OH}$ & $\rightarrow \mathrm{H}_{2} \mathrm{O}$ & 3.2 & .61 & .40 \\
$\mathrm{e}^{-}+\mathrm{OH}$ & $\rightarrow \mathrm{OH}^{-}$ & 3.0 & .73 & .53 \\
$\mathrm{e}^{-}+\mathrm{H}+\mathrm{H}_{2} \mathrm{O}$ & $\rightarrow \mathrm{H}_{2}+\mathrm{OH}^{-}$ & 2.4 & .43 & .25 \\
$\mathrm{e}^{-}+\mathrm{H}_{3} \mathrm{O}^{+}$ & $\rightarrow \mathrm{H}+\mathrm{H}_{2} \mathrm{O}$ & 2.3 & .40 & .21 \\
$\mathrm{H}+\mathrm{H}^{-}$ & $\rightarrow \mathrm{H}_{2}$ & 2.1 & .25 & .10 \\
$\mathrm{OH}^{-\mathrm{OH}^{-}}$ & $\rightarrow \mathrm{H}_{2} \mathrm{O}_{2}(\mathrm{P}=1 / 7)$ & 0.6 & .60 & .16 \\
$\mathrm{e}^{-}+\mathrm{e}^{-}+2 \mathrm{H}_{2} \mathrm{O}$ & $\rightarrow \mathrm{H}_{2}+2 \mathrm{OH}^{-}$ & 0.6 & .20 & .08 \\
$\mathrm{H}_{3} \mathrm{O}^{+}+\mathrm{OH}^{-}$ & $\rightarrow 2 \mathrm{H}_{2} \mathrm{O}$ & 12.0 & 1.08 & 1.08 \\
$\mathrm{e}^{-}+\mathrm{H}_{2} \mathrm{O}_{2}$ & $\rightarrow \mathrm{OH}^{-}+\mathrm{OH}^{-}(\mathrm{P}=1 / 3)$ & 1.2 & .60 & .25 \\
\hline
\end{tabular}

Table II 


\begin{tabular}{lcc}
\hline Reaction & $\mathrm{R}(\mathrm{nm})$ & $\mathrm{a}(\mathrm{nm})$ \\
\hline Sugar $+\mathrm{OH}$ & .38 & .28 \\
Sugar $+\mathrm{H}$ & .18 & .08 \\
Base $+\mathrm{OH}$ & .59 & .48 \\
Base $+\mathrm{e}$ & .56 & .42 \\
Base $+\mathrm{H}$ & .39 & .24 \\
\hline
\end{tabular}

Table III 
14

Figure Captions

Figure 1. Positions of reactant species in $4-\mathrm{MeV}$ alpha, 1-MeV, and $10-\mathrm{MeV}$ proton tracks.

Figure 2. Positions of reactant species in a 4-MeV alpha track at various times.

Figure 3. Reactant-reactant and reactant-DNA interactions for various particles. Impact parameter $=0$.

Figure 4. DNA interactions from proton and alpha particles of various energies. 
OANL-DWG 85-10000

\section{4-MeV ALPHA}

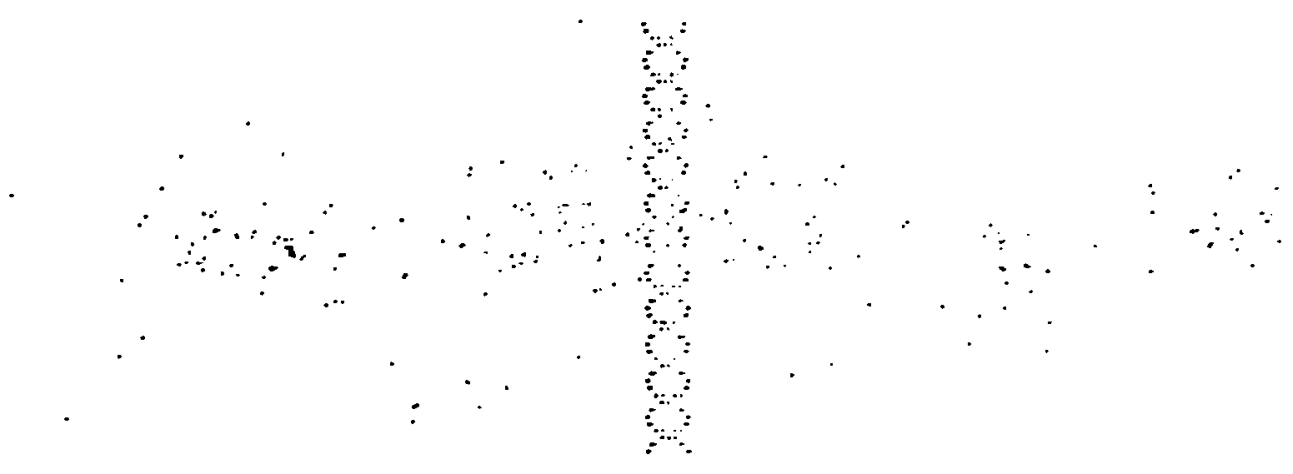

\section{1-MEV PROTON}

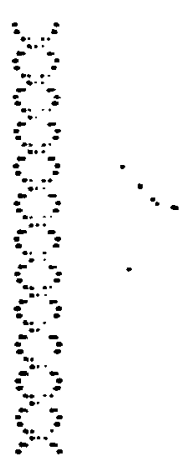




\section{4-MeV ALPHA}

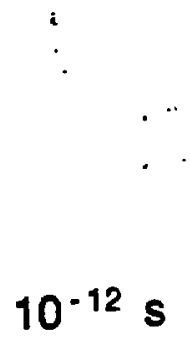

$10^{-10} \mathrm{~s}$
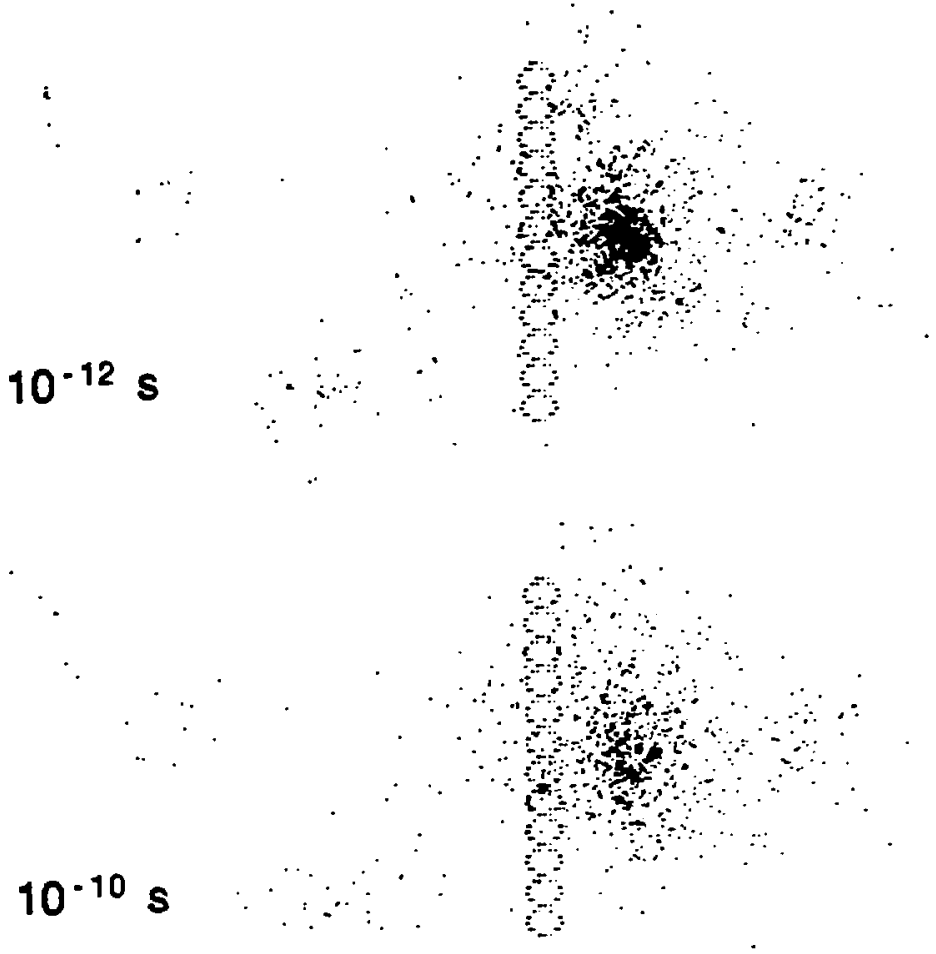

$10^{-B} \mathrm{~s}$

Figure 2 
ORNL-DWG 85C-9970

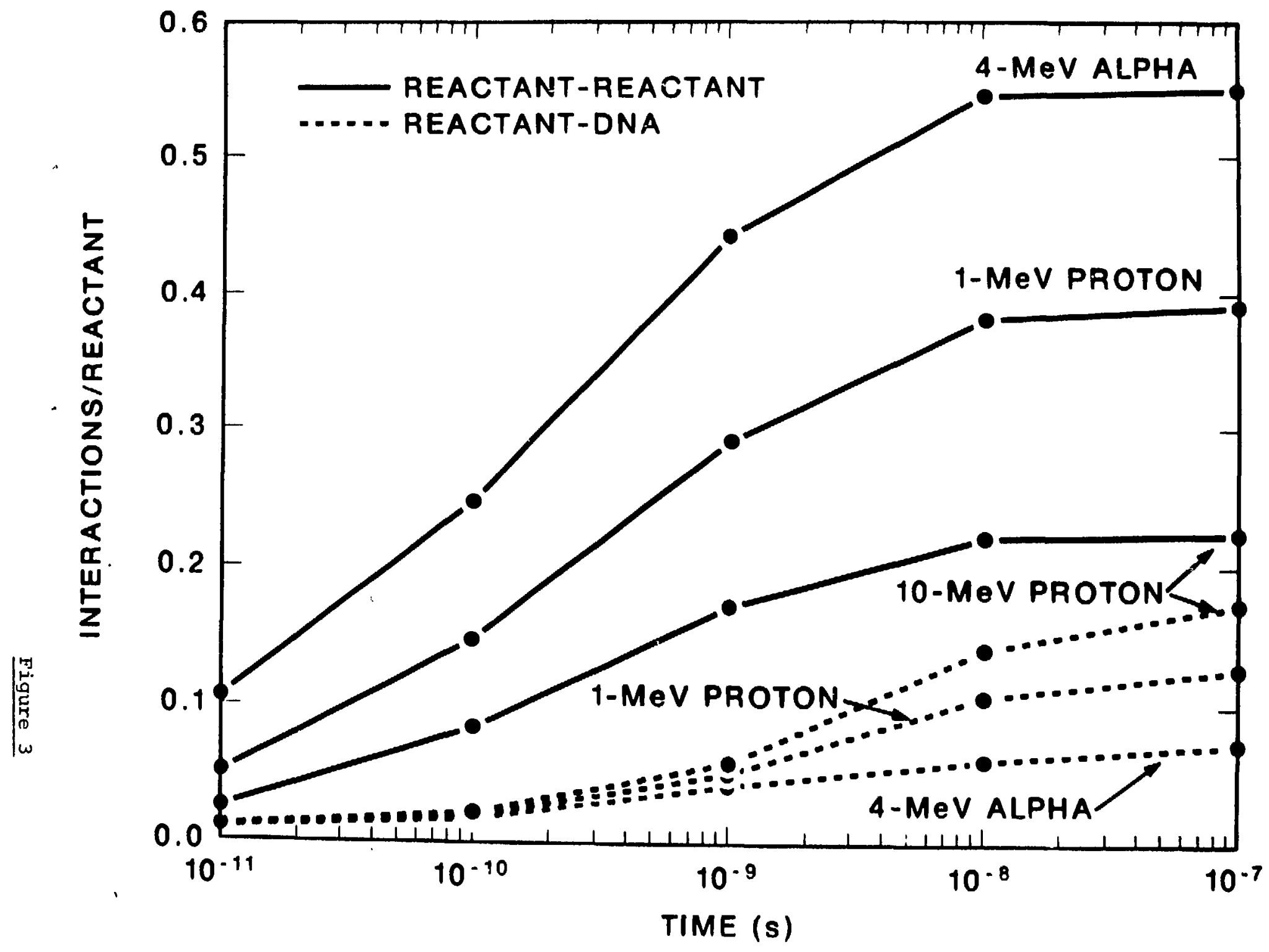


ORNL-DWG 85C-9972

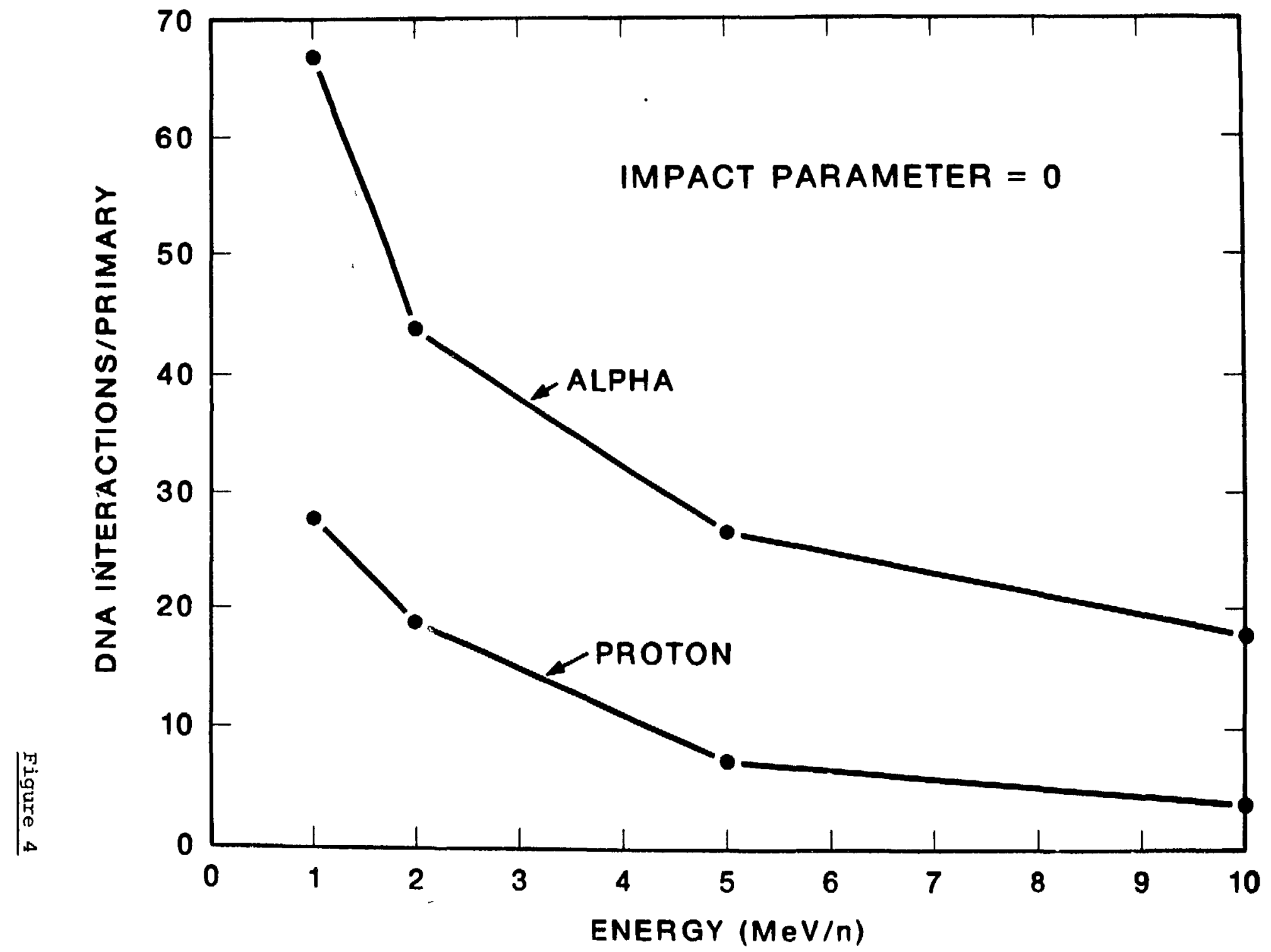

